\title{
Chagas' Disease: The Rural Environment and Vector Control in the State of São Paulo, Brazil
}

\section{Doença de Chagas: Meio Rural e Controle de Vetores no Estado de São Paulo, Brasil}

\section{Dalva Marli V. Wanderley ${ }^{1}$}

\section{WANDERLEY, D. M. V. Chagas' Disease: The Rural Environment and Vector Control in the} State of São Paulo, Brazil. Cad. Saúde Públ., Rio de Janeiro, 9 (4): 466-476, Oct/Dec, 1993. In the first half of this century - a period of expanding coffee cultivation - there was a close relationship between the growth of cleared spaces, the domestication of triatomines, and the establishment of Chagas' disease in the state of São Paulo. However, the initiation of control mesuares in 1950 coincided with a period characterized by a progressive reversal of the conditions that had facilitated the establishment of Chagas' disease in the first place. Alterations were taking place in the agricultural environment, rural areas were becoming depopulated, and low-grade housing was being destroyed. Natural transmission of the endemic was interrupted in the mid-1970's, following the elimination of Triatoma infestans from homes. Subsequently, however, a challenge emerged from two extradomiciliary species, Triatoma sordida and Panstrongylus megistus. The invasive character of these species made it necessary to investigate their possible repercussions on human populations and to set up permanent programs of epidemiological surveillance involving direct participation by local populations.

Key words: Trypanosomiasis; Chagas' Disease; Epidemiological Surveillance; Vector Control

\section{INTRODUCTION}

Studies on the domiciliarity of the triatomine vectors of Chagas' disease in Brazil show that this process has been associated with the distribution of open spaces (Forattini et al., 1970).'These [open spaces] can be regarded as natural or artificial. The former are found in regions characterized by semiarid 'caatinga' and grassy 'cerrado', entirely within Brazilian territory, as well as by landscape types that stretch beyond these limits. The artificial spaces, on the other hand, have their origins in human activities that have led to an expansion of open landscapes following destruction of forest cover" (Forattini, 1980).

Studies involving the reconstruction of

${ }^{I}$ Superintendência de Controle de Endemias da Secretaria de Estado de Saúde de São Paulo. Rua Paula Souza, 166, $1^{\circ}$ andar, São Paulo, SP, 01027-000, Brasil. historical patterns of forestation in the state of São Paulo, carried out by the Conselho Estadual do Meio Ambiente (Consema, 1985), estimate that originally $81.8 \%$ of the state's total area was under forest cover, whereas this figure has now been reduced to $5 \%$.

Historically, several different factors have played a role in causing this change. Initial deforestation resulted from the coffee boom, and then from the expansion of the railways. Subsequently, agricultural diversification mainly into cotton, oranges, and sugar cane was carried out without any attempt at planning. The same happened with charcoal output, which was carried out to meet rapidly growing industrial demand for fuel. Today this process continues, thanks to indiscriminate and savage deforestation.

In addition to deforestation, various other factors have been associated with modifications to the rural environment and have played a part in influencing triatomine distribution. The process of land occupation 
and settlement has been of critical significance, with housing conditions, in particular, being regarded as crucial determinants of the presence or absence of domiciliated species of triatomines. These related processes involving deforestation, settlement and construction of houses have operated in different ways at different times, initially facilitating, but then impeding, the establishment of Chagas' disease.

This paper, as well as charting these related processes, and exploring their influence on the occurrence and distribution of triatomine domiciliarity and Chagas' disease in the state São Paulo, presents an account of the measures used both to control disease transmission and to maintain vigilance against vectors.

\section{METHODOLOGICAL NOTE}

The destruction of forest cover in the state of São Paulo occurred after the discovery of Chagas' disease in 1909, and this paper divides the historical record into a number of periods relating to key stages in the development of SUCEN's disease control program. Since its inception in 1950, the program has generated a wealth of information which, herein, is analyzed in associaton with data on modifications to the rural environment (understood here to signify land occupation and settlement, including style of housing construction).

\section{0 to 1950}

A number of related developments took place during this period: Chagas' disease spread in the state of São Paulo; open spaces increased as a result of deforestation; triatomines were domesticated, with human houses becoming efficient dispersive environments; and coffee cultivation evolved.

The disease spread significantly over the course of this period, especially in the West, as is clear from a comparison of endemic municipalities (i.e. municipalities with a significant infestation of Triatoma infestans, the principal vector of Trypanosoma cruzi to humans) between 1916 and 1941 (Figures 1 and 2). In 1950, the pattern of triatomine infestation was such that these insects were collected in 231 out of a total of 369 municipalities in the state of São Paulo, with infected bugs being found in 148 municipalities. Out of a sample of 12,530 captured insects, $91.9 \%$ were $T$. infestans, $7.4 \%$ were Panstrongylus megistus, and $0.7 \%$ were Triatoma sordida (Buralli, 1985).

Data on the extent of forest cover in the state (Figure 3) show that, between 1920 and 1952, primary forest cover declined by 26.6 percentage points from $44.8 \%$ of the state in 1920 to $18.2 \%$ in 1952 . A closer study of the two maps for 1920 and 1952 shows that the expansion of open spaces occurred predominantly in an East-West direction, coinciding with the growing distribution of

FIGURE 1. Presence of Triatoma infestans in the State of São Paulo, Brazil, 1914

Source: Buralli, 1985.

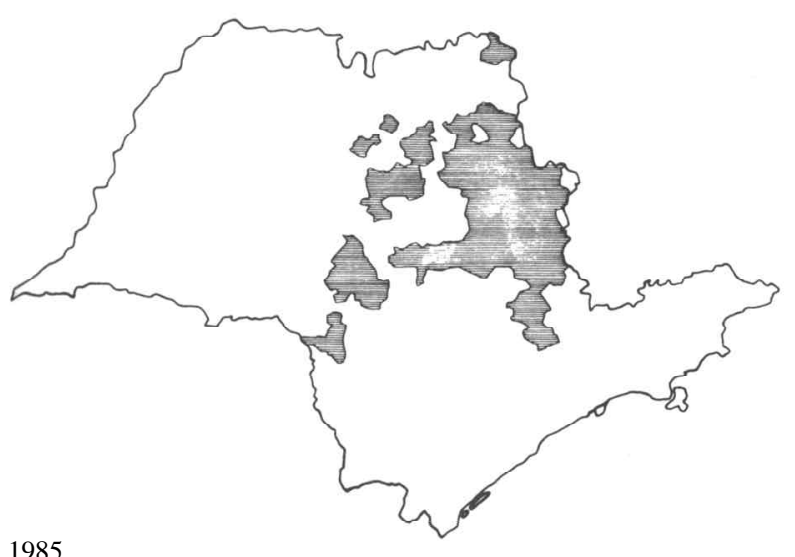


FIGURE 2. Presence of Triatoma infestans in the State of São Paulo, Brazil, 1941

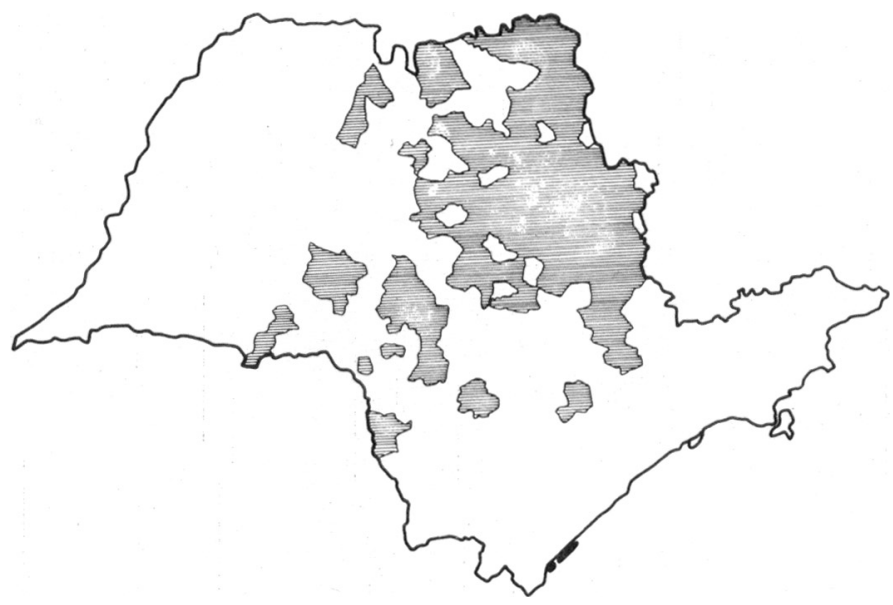

Source: Byralli, 1985.

FIGURE 3. Reconstruction of Historical Patterns of Forestation in the State of São Paulo
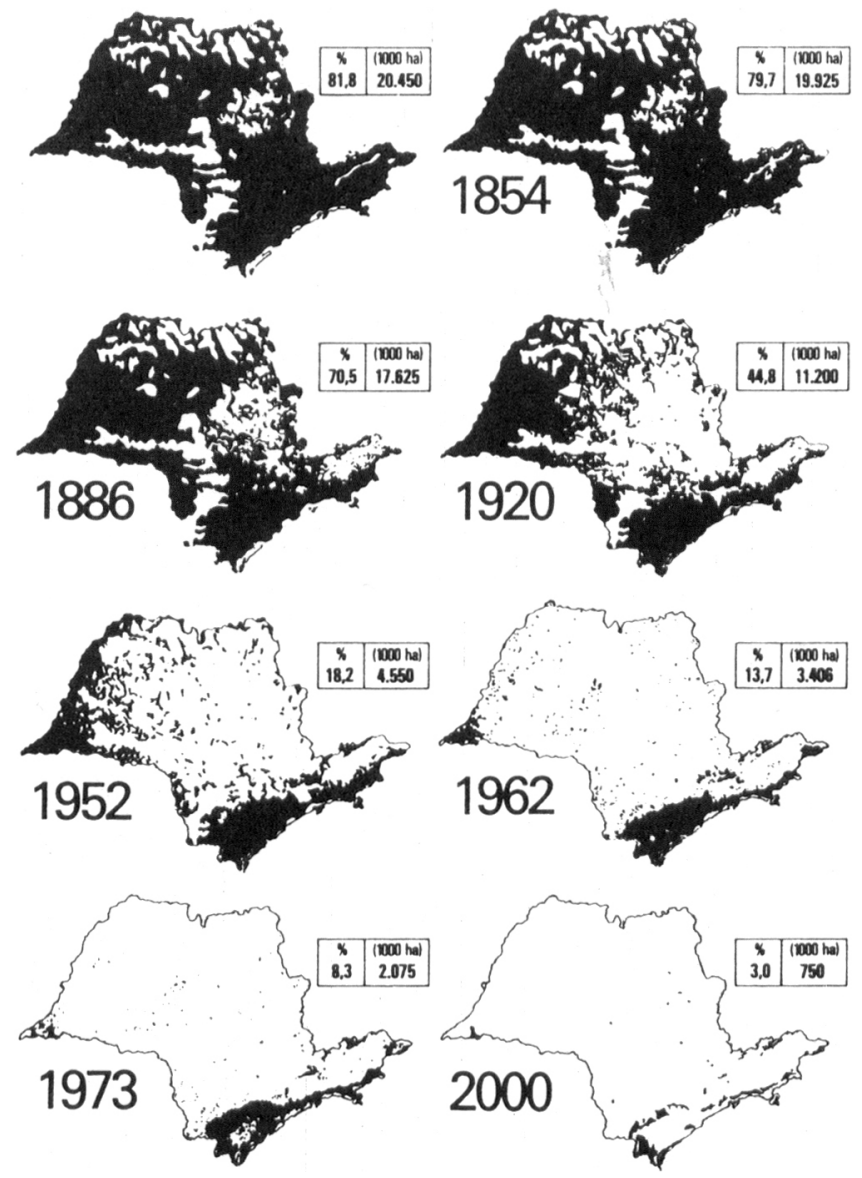

Source: CONSEMA, 1985. 
triatomines and of endemic Chagas' disease, and with the advancing agricultural frontier, the latter driven mainly by an increase in large-scale coffee cultivation. These aspects of the epidemiology of Chagas' disease in the state of São Paulo have been very well investigated by Silva et al. (1979); Silva (1981), and Buralli (1985).

\section{0 to 1962}

In 1950, a control program against Chagas' disease vectors was initiated in the state of São Paulo, using 30\% BHC in rural houses. The campaign continued until 1958, and was characterized by a constantly repeating cycle of insecticide use followed by insect capture. "This was due to technical and operational failings, resulting from inexperience and, above all, from a lack of continuity in the work, as well as from administrative factors associated with budget swings" (Rocha \& Silva et al., 1979). At the end of the 1950's, disease prevalence in the human population was found to be $9.3 \%$, with all age groups affected. The control program suffered from a lack of continuity until the mid-1960's, when the successful outcome of the attack against malaria led to the release of financial, material and human resources in sufficient quantities to permit a more intense campaign against Chagas' disease vectors. Between 1953 and 1963 there was a decline of 4.2 percentage points in the number of naturally infected T. infestans. Meanwhile, a significant presence of $T$. sordida was observed, and numbers of $P$. megistus remained stable at a relatively low level (Table 1). The map in Figure 4 shows the municipalities in which $T$. infestans was present in 1951.

In this period, at the same time as the program's entomological data showed that the spread of T. infestans had been contained, other data revealed that primary forest cover was reduced by a further 4.5 percentage points (Figure 3).

According to Silva (1981), during the 1950's the entire territory of the state of São Paulo became occupied, thus ending a long process of progressive colonization in the hinterland, a process which had been driven by the expansion of coffee cultivation and had lasted almost a century. The nation's internal frontiers of occupation and settlement moved to Paraná, Mato Grosso and Goiás. The migration of rural labour to large urban centres intensified during the 1950's. From 1957 onwards, the rural population in the state of São Paulo began to fall in absolute terms. In the following decade, at the end of which it became clear that natural transmission of Chagas' disease had been

FIGURE 4. Presence of Triatoma infestans in the State of São Paulo, Brazil, 1951

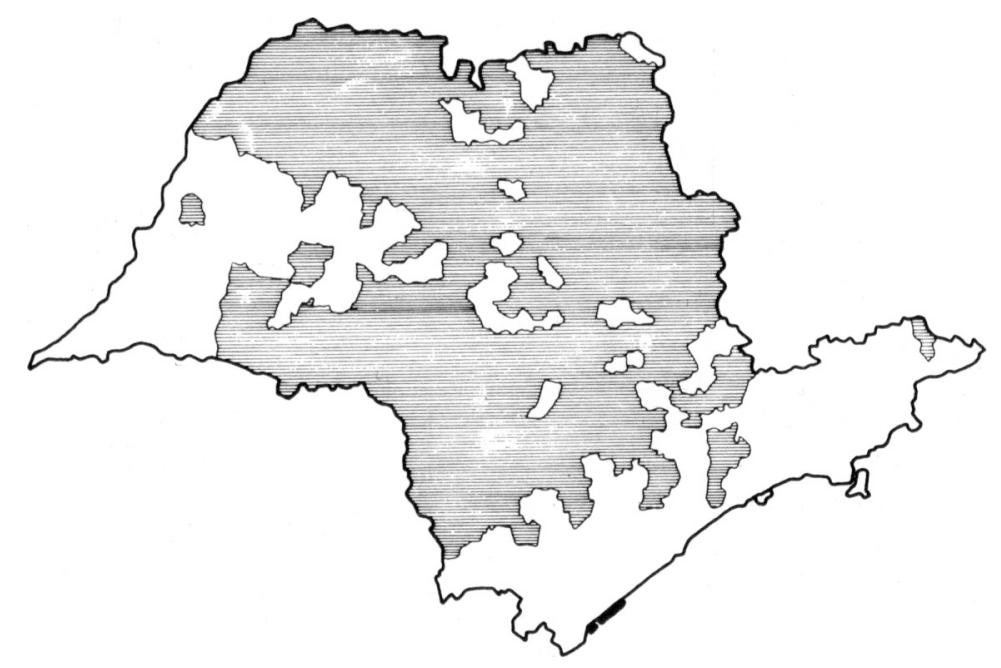

Source: Buralli, 1985. 


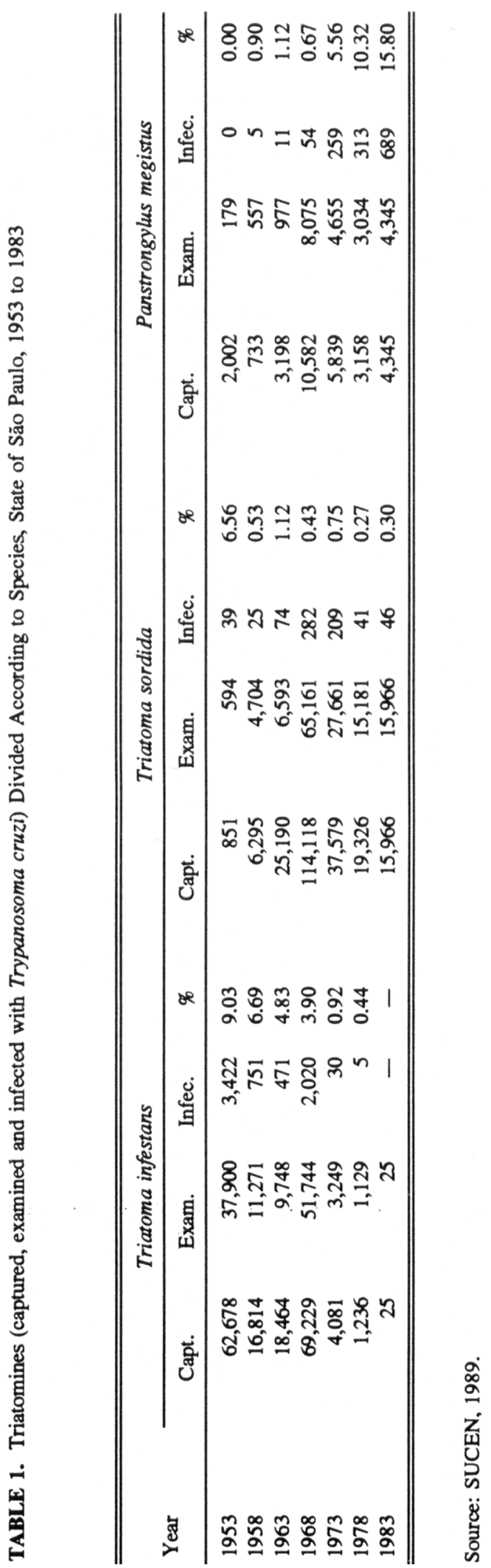


interrupted, the process of rural depopulation accelerated. Today, the decline in the number of rural houses has been translated into a decline in the availability of ecotopes for $T$. infestans. The rural exodus - still according to Silva - is associated with a reduction in the number of homes in rural areas, and this reduction takes place on a selective basis whereby, of the houses destroyed, a relatively high proportion are of the lowest grade.

Thus, in the period 1950-1962, the destruction of forest cover, the occupation of agricultural space, the rural exodus and the reduction in the number of lowest-grade houses constituted a network of interrelated factors that served to overturn the conditions that, from 1920 to 1950 , had fostered the spread of Chagas' disease in the state of São Paulo.

\section{2 to 1973}

This period saw a considerable decline in the number of captured specimens of $T$. infestans $(77.8 \%)$, together with a 3.9 percentage point fall in the rate of natural infection (Table 1). These changes were associated with an estimated $26.9 \%$ reduction in the rural population (Silva, 1981). It was precisely during this period that entomological data, in addition to serological data from schoolchildren, suggested that natural transmission of Chagas' disease had come to an end in the state of São Paulo (Souza et al., 1984; Wanderley, 1987). The previously extensive distribution of $T$. infestans was reduced to a few limited areas - the regions of Sorocaba and São José do Rio Preto (Figure 5) - where the level of household infestation, the number of insects, and their natural rate of infection suggested that transmission was unlikely to occur. In these areas, there was still a high percentage of adobe houses among the rural dwellings surveyed each year by staff working on the control program. In 1973, according to Caldas Jr. (1983), $38.3 \%$ and $26.5 \%$ of all surveyed houses in Sorocaba and São José do Rio Preto, respectively, were constructed from adobe.

In "clean" areas, free of $T$. infestans, the two other main species of triatomine $-T$. sordida (Figure 6) and P. megistus (Figure 7) - continued to be found, being less susceptible than $T$. infestans to the control methods used.

FIGURE 5. Geographical Distribution of Triatoma infestans in the State of São Paulo, 1972

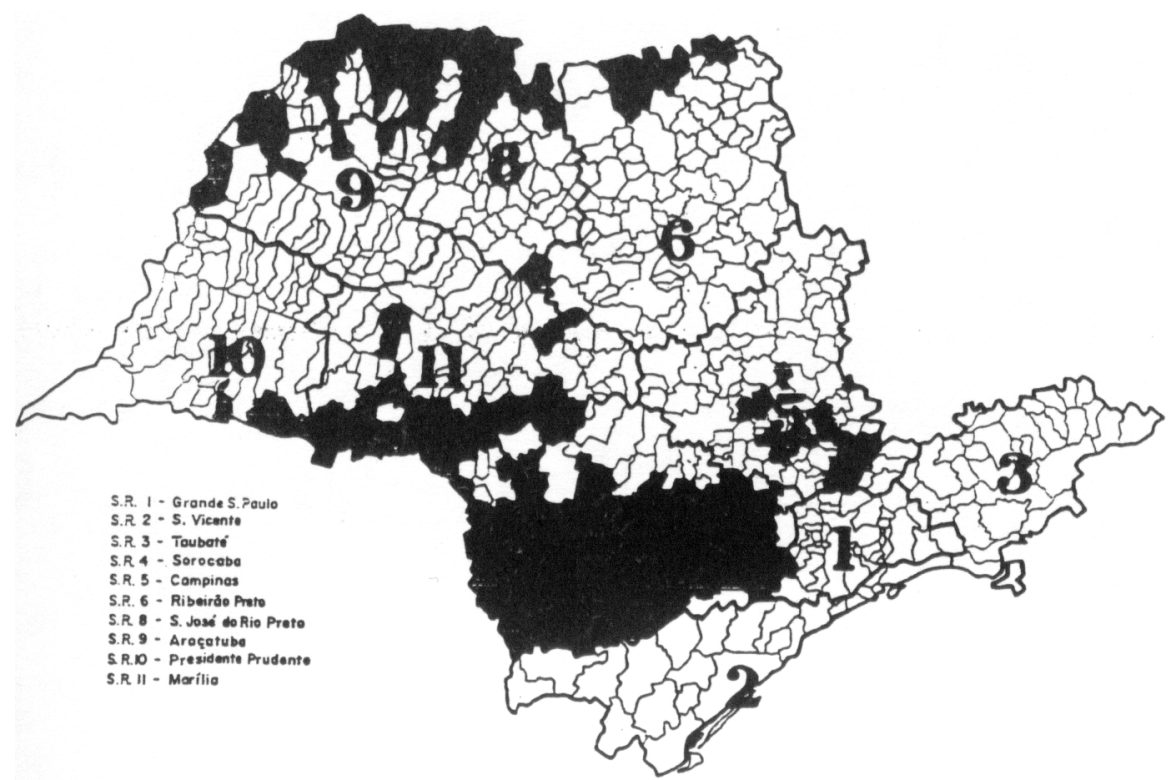

Source: SUCEN, 1989. 
FIGURE 6. Geographical Distribution of Triatoma sordida in the State of São Paulo, 1972

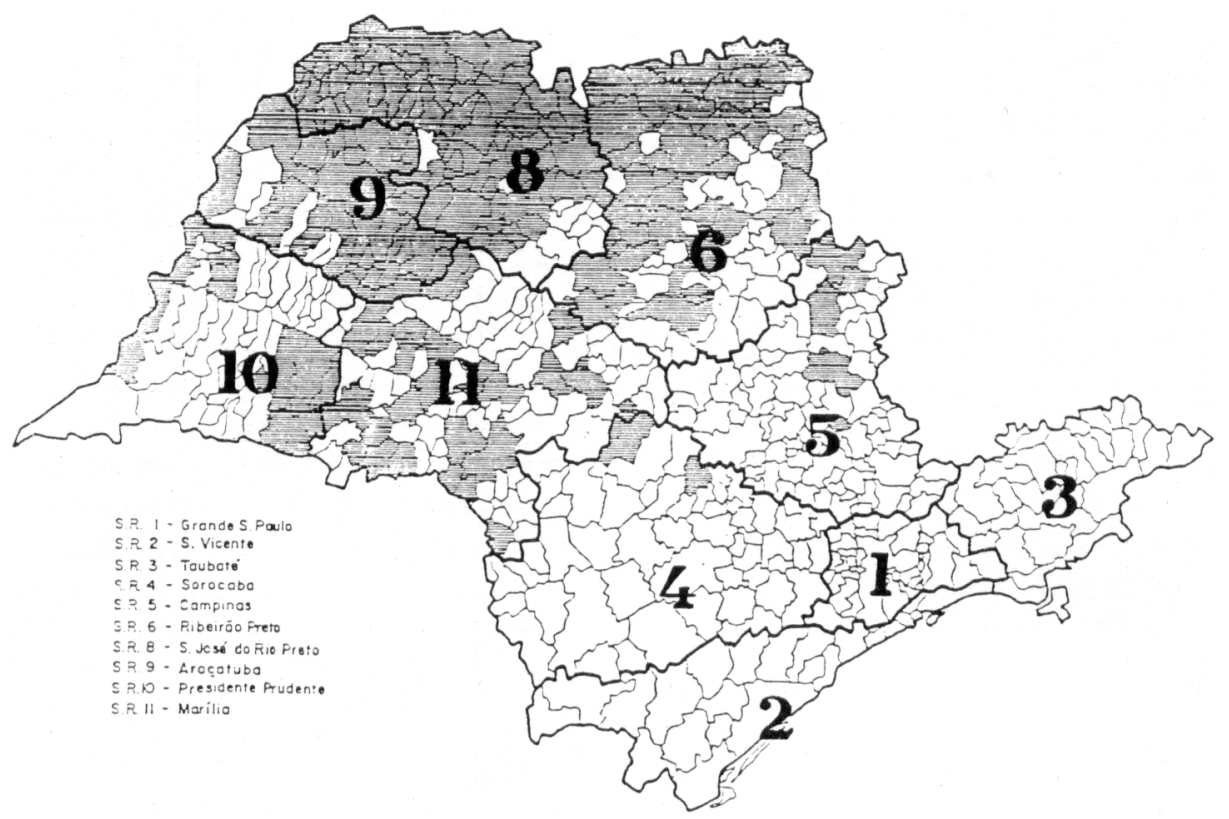

Source: SUCEN, 1989.

FIGURE 7. Geographical Distribution of Panstrongylus megistus in the State of São Paulo, 1972

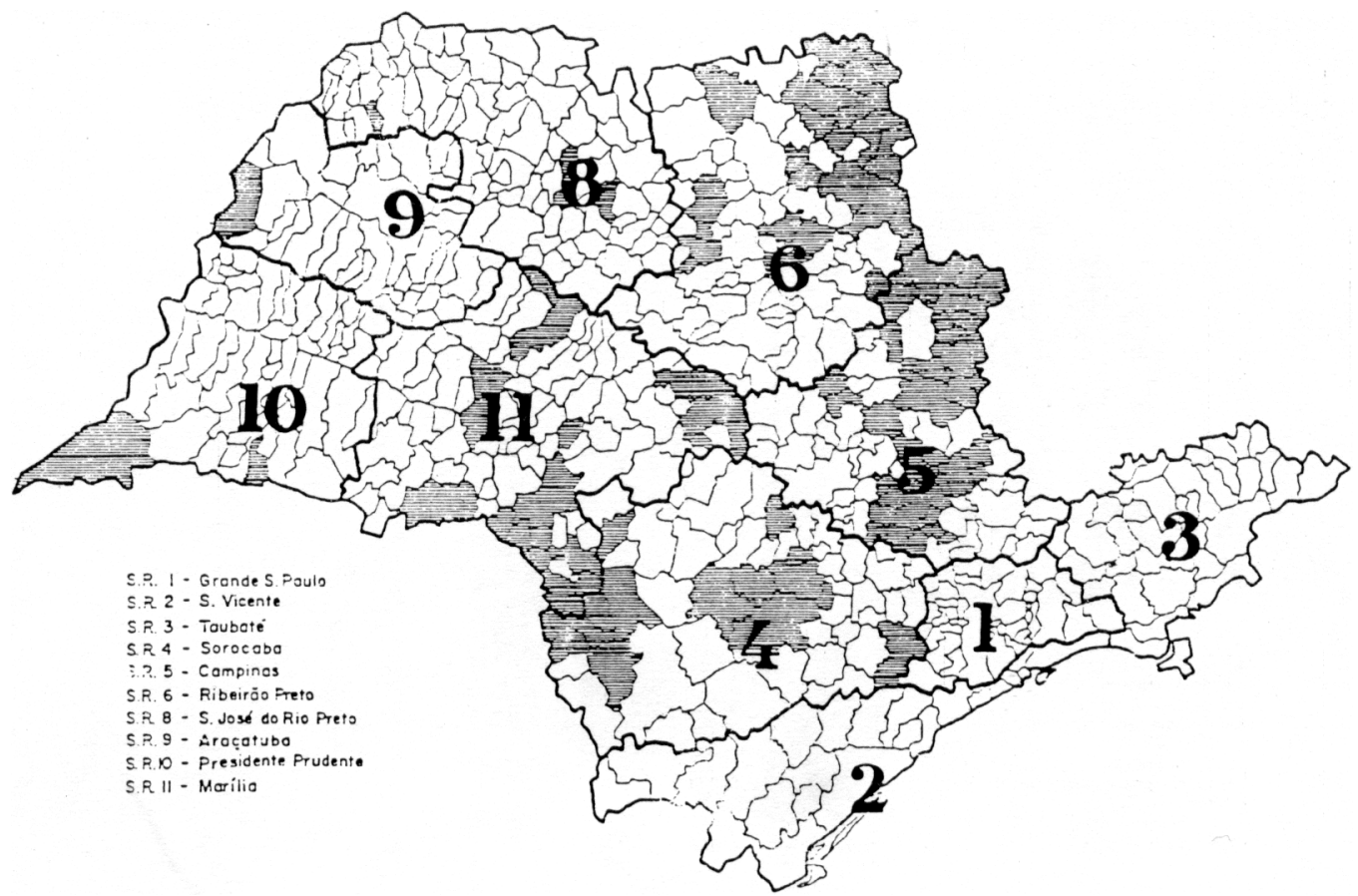

Source: SUCEN, 1989. 
As for the forests, there was a further reduction of 5.4 percentage points in the amount of forest cover between 1962 and 1973, leaving only $8.3 \%$ of São Paulo's land area under forest cover in 1973 (Consema, 1985). Meanwhile, as far as the open spaces were concerned, coffee gave way to livestock and sugar cane in many areas, with a consequent decline in the demand for agricultural workers (seasonal/part-time labour).

During this period - or, more specifically, in 1970 - Forattini et al. (1970) commenced their studies, to be published in the series "Aspectos ecológicos da tripanossomíase americana" (Ecological aspects of American trypanosomiasis), including 21 articles and finished in 1984. Designed to increase scientific understanding of the role played by secondary vector species in the bioenvironment of Chagas' disease, these studies answered many of the questions raised during the course of the control program: could the interruption of natural transmission be reversed, with the secondary species $T$. sordida and P. megistus filling the ecological niche previously occupied by $T$. infestans, but now empty, thus leading to reinfestation of the old areas ? Leaving aside the potential risks of transmission posed by these triatomines, was it acceptable for the rural population to carry on living side by side with blood-sucking insects?

Forattini et al. (1970) carried out studies on the mechanisms of triatomine adaptation to the human environment, using artificial ecotopes (experimental chicken coops) erected in several locations in the state of São Paulo. The chosen locations represented a range of different levels of landscape modification by humans, and were characterized by varying degress and types of triatomine distribution. It was observed that $T$. sordida has its centre of dispersal in the grassy cerrado areas of the Central Region, and that the principal areas of distribution of this species in the state of São Paulo are the Ribeirão Preto, São José do Rio Preto and Araçatuba regions. Overall, this species is fairly widely distributed in the state, owing to its relatively extensive ecological adaptability, which allows it to frequent a variety of ecotopes, many of them with a poor supply of potential food, but with considerable scope for reproduction. The insect displays high survival rates and elevated production of adults, as well as successfully taking advantage of modifications to the natural environment. Adult specimens are mainly found during the first half of the year, with dispersal and formation of new foci occurring from March onwards, and continuing until July in some cases. This long period of dispersal and high survival favours the proliferation of the species.

However, in regions where the land is frequently worked (sugar cane plantations, pasture), a progressive decline in the presence of this native species has been observed, probably as a result of a reduction of its natural ecotopes. On the other hand, studies show that when the native species is broadly dispersed in a peridomiciliary silvatic environment, normal control methods are problematical. Various factors may be instrumental in reducing the effectiveness of control: the difficulty of detecting and combatting insects in their natural environment; the relative inefficiency of certain insecticides when used in open environments; the apparently low susceptibility of some species to these insecticides.

T. sordida uses a wide variety of different food sources, with birds being the principal providers. Apart from birds, many kinds of domestic and synanthropic animal play a part, incluiding gambá opossums (Didelphis) and rats. The insect's feeding habits are in fact largely dictated by "opportunity", with invasion occurring most intensely in ecotopes containing a greater number of food sources. The presence of mammals in the food chain facilitates the circulation of $T$. cruzi within insect populations, thus helping to maintain the parasitosis.

The authors highlight the impact of insecticide use on the domiciliarity of this species. After more than 10 years of research, there was no confirmation of certain initial suppositions, such as "it is to be expected that the ecological niche left empty following the elimination of other domiciliated triatomine 
populations will be quickly occupied by $\underline{T}$. sordida". Studies carried out by Buralli (1985) in 36 municipalities in the São José do Rio Preto region - an area that underwent extensive treatment between 1968 and 1980, and that initially contained fairly high densities of T. infestans and T. sordidaalso failed to confirm this hypothesis.

Forattini et al. (1970) also observed that the centre of dispersal of $P$. megistus lies in forested areas, where survival is favoured by rainfall, relatively high humidity and the prevalent type of plant cover. Following deforestation, the species resides in residual forests containing a wide variety of food sources. The insect displays a certain preference for marsupial from the genus Didelphis and for silvatic rodents, a preference from which its propensity for a relatively high level of infection with $T$. cruzi is derived. In residual forests surrounded by open spaces, it displays a still more highly developed level of ecological adaptability, tending to migrate to new environments that are then colonized, with domiciliarity often occurring in the process. Any further intensification of environmental change will tend to induce the insect to limit its activity to the domestic environment. Dispersal occurs in clearly defined annual cycles. In the second half of the year, production of adults is at its peak, with dispersal into new foci occurring mainly in October and November. Given its high ecological adaptability and eclectic food consumption, this species can foster the circulation of $T$. cruzi in the human environment. Since it feeds on human blood, it can reintroduce or maintain the parasitosis.

With regard to the control of domiciliated insects, use of insecticides can eliminate infestation in houses and outbuildings. However reinfestation may occur, sometimes as much as two and a half years later. Vigilance should therefore include house surveys, with these being carried out every 3 years, in the final third of the year.

Experimental studies, together with data from the control program, suggest that secondary species are capable of colonizing the human environment, reinfesting clean areas (albeit slowly), and maintaining the circulation of $T$. cruzi in the new environment, albeit at a level that does not appear to include humans in the chain of transmission.

Existing evidence suggests that transmission is not occurring in areas occupied by $T$. sordida, nor in areas in which $P$. megistus has resisted control.

The monitoring of peridomiciliary environments requires permanent vigilance aimed at detecting new triatomine foci and investigating possible autochthonous cases of Chagas' disease. This inevitably involves local participation, and the community should always receive an immediate response when it reports the presence of vectors, whereupon it is the responsibility of the control service and the primary health system to investigate foci and apply chemical treatments when necessary.

Past research, combined with the results obtained in São Paulo's vector control program for Chagas' disease, has made it possible - over a period of three decades to establish a system of entomological vigilance to counter the disease.

\section{ENTOMOLOGICAL VIGILANCE IN THE CONTROL OF CHAGAS‘ DISEASE}

The creation of a vigilance system for Chagas" disease in rural areas in the state of São Paulo was intended to safeguard results that had already been obtained and to increase the efficiency of control initiatives. A number of factors favoured the creation of such a system:

- the natural transmission via domiciliated triatomines had already been interrupted, or was occurring at such a low level that it was not being reported through the existing notification system;

- the presence of T. infestans, the main vector, had been reduced to insignificant levels. Populations were limited to isolated residual foci and were tending towards extinction, since conditions in the rural environment no longer favoured an increase in domestic infestation; 
- T. sordida, although present over a wide geographical area, displayed low levels of infestation in houses and outbuildings, low levels of infection with T. cruzi and low levels of feeding on human blood. Despite its relatively low susceptibility to control measures, the insect population was nonetheless tending to decline, as a result of adverse conditions in its principal habitats. Today, residual populations tend to be distributed in clusters, rather than being found evenly dispersed throughout a given area. It is likely that these population clusters are confined to locations where environmental changes have been most favourable;

- P. megistus, although much more limited than T. sordida in its geographic distribution, presents a similar picture. In a few areas, high densities of infected insects have been observed in certain foci, with insect colonies being found principally in outbuildings and abandoned houses;

- due to the specific characteristics of the domiciliarity processes typical of T. sordida and P. megistus, the most effective way of discovering new foci was found to be through responding to reports given by local residents.

In the light of these circumstances, entomological vigilance initiatives were set in motion form 1984 onwards, and consolidated in 1989, with the following results: of the 8,569 locations in which triatomine surveys were carried out in the 4 year period (1985$1988), 76 \%(6,485)$ had intra- and peridomiciliary infestation rates of zero; $15 \%$ $(1,308)$ had intradomiciliary infestation rates of $0-5 \%$ and peridomiciliary rates of $0-10 \%$; and only $9 \%$ (776) had rates higher than these.

Data on capture rates for the three most significant species in the state of São Paulo gave the following picture: T. sordida was the most common species, accounting for $82.6 \%$ of the total number of captured insects, with $74 \%$ being found in peridomiciliary areas; $P$. megistus accounted for $17.3 \%$, with a relatively high incidence in intradomiciliary locations (48\%); and T. infestans occurred only sporadically, accounting for $0.1 \%$ of the total, with all captured specimens being found in intradomiciliary locations.

As for vigilance activities aimed at assessing the risk of natural transmission, the following findings can be highlighted: average rates of infection with $T$. cruzi were $9 \%$ for P. megistus and $1.0 \%$ for T. sordida; $5 \%$ of captured specimens were using humans as food sources; the prevalence of chagasic infection among residents of houses containing triatomines was $3.56 \%$, with the vast majority of serologically positive subjects being over 19 years of age. These data confirm the absence of natural transmission in the state of São Paulo.

One interesting aspect of the control program in São Paulo - noted in a previous publication (Wanderley, 1991) — is the issue of community participation in Chagas' disease vigilance programs. The community plays an important role in bringing insects suspected of being triatomines to the attention of the control service. However, it was noted that, although $78 \%$ of the triatomines captured inside houses were supplied by residentes, $92 \%$ of the peridomiciliary foci were detected by the staff of the control service. These data reflect the present distribution of triatomines in the state (peridomiciliary) and the capacity of the insects to invade human habitations (intradomiciliary).

As from 1990, the São Paulo control program remains committed to the following objectives: the capture of insects, with the aim of assessing the possible repercussions of triatomine populations on humans, and the discovery of infested foci requiring control. The following broad guidelines are being applied:

- triatomine research activities should be directed towards infested areas, with the aim of improving their effectiveness; and

- notification procedures should be given priority, since these are highly efficacious in assisting the discovery of invasive triatomines and in the identification of suspected foci. 


\section{ACKNOWLEDGEMENTS}

I am grateful to Prof. Dr. Oswaldo Paulo Forattini, of the Faculty of Public Health at the University of São Paulo, and to Geraldo Magela Buralli, for inspiration and stimulation, and for assistance in revising the manuscript.

\section{RESUMO}

\section{WANDERLEY, D. M. V. Doença de}

Chagas: Meio Rural e Controle de Vetores no Estado de São Paulo, Brasil. Cad. Saúde Públ., Rio de Janeiro, 9 (4): 466-476, out/dez, 1993.

O presente estudo analisa as relações entre a expansão dos espaços abertos, a domiciliação triatomínea e a instalação da doença de Chagas no Estado de São Paulo durante a expansão da cultura cafeeira, na primeira metade do século. No período pós-50, o início das ações de controle coincide com a desestruturação das relações facilitadoras para a instalação da doença de Chagas, através da alteração do espaço agrário, êxodo rural e destruição de domicílios de pior qualidade. A partir da interrupção da transmissão natural da endemia, em meados da década de 70, consequiência da eliminação de Triatoma infestans dos domicílios, enfrenta-se o desafio das populações triatomíneas extradomiciliares - Triatoma sordida e Panstrongylus megistus —, cujo caráter invasivo tem requerido a investigação das possíveis repercussões humanas da sua presença, através da vigilância epidemiológica permanente com participação da população.

Palavras-Chave: Triatomíneos; Vigilância Epidemiológica; Controle de Vetores; Doença de Chagas

\section{REFERENCES}

BURALLI, G. M., 1985. Estudo do Controle dos Triatomíneos Domiciliados no Estado de São Paulo. Tese de Mestrado, São Paulo: Faculdade de Saúde Pública, Universidade de São Paulo.
CALDAS Jr., A. L., 1983. Epidemiologia e Controle de Doença de Chagas: Relação com a estrutura agrária na região de Sorocaba - SP. Tese de Mestrado, São Paulo: Faculdade de Medicina, Universidade de São Paulo.

CONSEMA (Conselho Estadual do Meio Ambiente), 1985. Áreas Naturais do Estado de São Paulo. São Paulo: Consema.

FORATTINI, O. P., 1980. Biogeografia, origem e distribuição da domiciliação de triatomíneos no Brasil. Revista de Saúde Pública, 14: 265-99.

FORATTINI, O. P., RABELLO, F. X.; CASTANHO, M. L. S. \& PATTOLI, D. G. B., 1970. Aspectos ecológicos da tripanossomíase americana.__ I - Observações sobre Panstrongylus megistuse suas relações com focos naturais da infecção, em área urbana da cidade de São Paulo, Brasil. Revista de Saúde Pública, 4: 1930.

ROCHA E SILVA, E. O.; GUARITA, O. F. \& ISHIHATA, G. K., 1979. Doença de Chagas: Atividades do controle dos transmissores no Estado de São Paulo, Brasil. Revista Brasileira de Malariologia e Doenças Tropicais, 31: 99-119.

SILVA, G. R.; LITVOC, J.; GOLDBAUM, M. G. \& DIAS, J. C. P., 1979. Aspectos da epidemiologia da doença de Chagas. Ciência e Cultura, 31 (supl.): 81-103.

SILVA, L. J., 1981. Evolução da Doença de Chagas no Estado de São Paulo. Tese de Doutorado, Ribeirão Preto. Faculdade de Medicina, Universidade de São Paulo.

SOUZA, A. G., 1984. Consolidation of the control of Chagas' disease vectors in the state of São Paulo. Memórias do Instituto Oswaldo Cruz, 79 (supl.): 125-131.

SUCEN (Superintendência de Controle de Endemias), 1989. Relatório do Grupo de Estudo do Programa de Controle da Doença de Chagas (Documento Interno). (Mimeo.)

WANDERLEY, D. M. V., 1987. A nálise da A tual Estratégia do Programa de Controle da Doença de Chagas no Estado de São Paulo. Tese de Mestrado, São Paulo. Faculdade de Saúde Pública, Universidade de São Paulo.

1991. Vigilância entomológica da doença de Chagas no Estado de São Paulo. Revista de Saúde Pública, 25: 28-32. 